Al-Madrasah: Jurnal Ilmiah Pendidikan Madrasah Ibtidaiyah

Vol. 6, No. 1, 2021

DOI 10.35931/am.v6i1.741

P-ISSN: 2620-5807; E-ISSN: 2620-7184

\title{
BARCODE SEBAGAI MEDIA PEMBELAJARAN BLENDED LEARNING PADA PELAJARAN IPS
}

\author{
Syarifuddin ${ }^{1}$, Muhammad Nasir ${ }^{2}$, Mardiana3 \\ 1,2,3 Dosen STIQ Amuntai, Kalimantan Selatan, Indonesia \\ ${ }^{1}$ Syarifuddin.stiq@gmail.com, ${ }^{2}$ nasirmuning@gmail.com \\ ${ }^{3}$ Mardianabiologi12@gmail.com
}

\begin{abstract}
Abstrak
Kegiatan belajar-mengajar pada peserta didik di sekolah sekarang mayoritas menggunakan Smartphone, semua ini disebabkan karena adanya wabah virus covid-19 yang menyerang dunia dan tanpa terkecuali Indonesia. Peserta didik dalam menggunakan smartphone harus diawasi dan dibantu orang tua, karena dalam smartphone begitu banyak informasi yang tidak bisa disaring oleh anak-anak, baik dari sesi positif dan negatifnya. Oleh karena itu perlu sesuatu alat yang dapat mengarahkan anak-anak dalam belajar dan lebih terfokus dengan materi pembelajaran. Barcode merupakan suatu gambar yang berbentuk abstrak yang bisa memunculkan tulisan, data, suara bahkan video. Manfaat dari media barcode ini diharapkan mampu membuat peserta didik menjadi lebih terfokus dengan pelajaran yang diberikan guru. Metodologi yang digunakan dalam pembuatan $(R \& D)$ tahapannya menggunakan model ADDIE. Media yang dikembangkan adalah media barcode. Hasil uji validasi pengembangan media barcode secara keseluruhan sudah lengkap dan sudah layak digunakan untuk kegiatan belajar mengajar di kelas. Media ini diharapkan akan membantu guru-guru dalam membuat bahan ajar yang simpel dan terfokus pada smartphone.
\end{abstract}

Kata Kunci: Barcode, Smartphone, Kertas Satu Lembar, Covid-19

\begin{abstract}
The majority of teaching and learning activities for students at school now use smartphones, all of this is due to the covid-19 virus outbreak that has attacked the world and Indonesia is no exception. Students in using smartphones must be supervised and assisted by their parents, because in smartphones there is so much information that cannot be filtered by children, both from positive and negative sessions. Therefore we need a tool that can guide children in learning and be more focused on learning material. Barcode is an abstract image that can display text, data, sound and even video. The benefits of barcode media are expected to be able to make students more focused on the lessons given by the teacher. The methodology used in making this one-sheet paper learning uses the Research and Development $(R \& D)$ methodology with several development stages 1) analysis, 2) design, 3) development, 4) implementation, and 5) evaluation. This research is expected to be able to assist teachers in making teaching materials that are simple and focused on smartphones.
\end{abstract}

Keywords: Barcode, Smartphone, One Sheet Paper, Covid-19

Al-Madrasah: Jurnal Ilmiah Pendidikan Madrasah Ibtidaiyah

Vol. 6, No. 1, Juli-Desember 2021 
Syarifuddin, Muhammad Nasir, Mardiana : Barcode Sebagai Media Pembelajaran Blended Learning Pada Pelajaran IPS

\section{PENDAHULUAN}

Cra industri 4.0 saat ini disebut juga dengan era digital, penggunaan $\mathrm{ICT}^{1}$ untuk menunjang kegiatan belajar mengajar dikelas dirasa sangat diperlukan, karena tuntutan zaman yang sudah tidak dapat dipungkiri lagi. Penggunaan media digital dapat membantu guru dalam menyampaikan materi, sehingga membantu guru dalam kegiatan belajar mengajar. Bahkan fungsi media digital dapat mengurangi dari penggunaan buku kertas, sehingga akan berdampak tidak langsung, bisa menjaga lingkungan dari sampah kertas.

Pada kenyataannya saat wabah covid-19 menyerang kota Wuhan China $^{2}$, dan hingga saat ini sudah mewabah ke seluruh penjuru dunia. Membuat keadaan semakin memaksa para pendidik untuk menggunakan media digital sebagai media untuk menunjang kegiatan belajar mengajar. Guru-guru dipaksa agas mampu membuat dan menggunakan media digital ${ }^{3}$ dalam pembelajaran. Dengan kondisi yang sangat mendesak ini, tidak sedikit guru yang kebingungan untuk menggunakan media digital, karena memang guru-guru yang ada sekarang tidak dipersiapkan untuk menghadapi era digital. Banyak guru yang kebingungan dan kewalahan terhadap kondisi seperti ini dikala pandemik ${ }^{4}$, di mana sekolah banyak yang menggunakan pembelajaran secara daring (dalam jaringan). Penggunaan media digital yang seharunya membuat guru-guru dan murid bisa belajar dengan asyik, pada kenyataannya guru dan murid malah menjadi kerepotan karena tidak ada persiapan tentang pembelajaran menggunakan digital. Oleh sebab itulah, perlu adanya media yang disusun dengan rapi dan mengasikan untuk digunakan dalam kegiatan belajar dan mengajar.

Era Teknologi atau bisa juga disebut era digital dalam era ini guru harus mampu menguasai literasi digital karena dapat memudahkan dalam pembuatan media pembelajaran ${ }^{5}$. Media belajar yang dibuat harus mengutamakan kemudahan, efisien, efektif dan kekinian. Berdasarkan hal tersebut maka dikembangkan suatu media yang bernama media barcode. Media ini merupakan suatu image dua dimensi yang dapat menampilkan data dalam bentuk teks, sehingga mampu menjadi alat interaksi antara guru dan siswa dalam metransfer pengetahuan dan informasi. Media barcode diharapkan mampu menjadi suatu media belajar yang kekinian berbasis digital

\section{METODE PENELITIAN}

Jenis penelitian ini adalah Research \& Development (R\&D). Adapun tahapannya menggunakan model ADDIE dengan rincian pada gambar 3.01 di bawah:

${ }^{1}$ Sri Wilda Albeta, Nofianti Nofianti, dan Sri Rahmandani, "Peranan Turnamen Berbasis Ict Dengan Aplikasi Quizizz Terhadap Pembelajaran Kimia," Jurnal Pendidikan Kimia Universitas Riau 5, no. 1 (28 Januari 2020): 11, https://doi.org/10.33578/jpk-unri.v5i1.7778.

${ }^{2}$ Kompas Cyber Media, "Diumumkan Awal Maret, Ahli: Virus Corona Masuk Indonesia dari

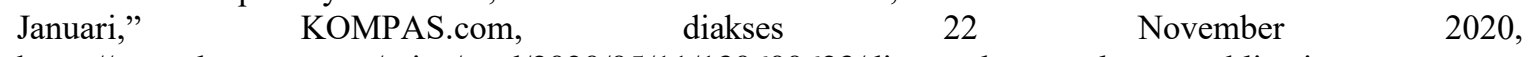
https://www.kompas.com/sains/read/2020/05/11/130600623/diumumkan-awal-maret-ahli--virus-coronamasuk-indonesia-dari-januari.

${ }^{3}$ Rasyid Hardi Wirasasmita dan Muhammad Zamroni Uska, "Pengembangan Media Pembelajaran Berbasis Buku Digital Elektronic Publication (Epub) Menggunakan Software Sigil Pada Mata Kuliah Pemrograman Dasar," Edumatic : Jurnal Pendidikan Informatika 1, no. 1 (27 Desember 2017): 12.

${ }^{4} 160209063$ Nindia Taradisa, "Kendala yang Dihadapi Guru Mengajar Daring Pada Masa Pandemi Covid-19 di Min 5 Banda Aceh," Kendala yang Dihadapi Guru Mengajar Daring Pada Masa Pandemi Covid-19 di Min 5 Banda Aceh, 20 Agustus 2020, 1.

${ }^{5}$ Syarifuddin, "Bimbingan Penggunaan Google Form Untuk Pembelajaran IPS Pada Madrasah di Banua Enam | Syarifuddin | Manhaj: Jurnal Penelitian dan Pengabdian Masyarakat," Manhaj: Jurnal $\begin{array}{lllllll}\text { Penelitian dan Pengabdian Masyarakat 9, no. } 1 & \text { (2020): 47, }\end{array}$ http://dx.doi.org/10.29300/mjppm.v9i1.3002.g2479.

Al-Madrasah: Jurnal Ilmiah Pendidikan Madrasah Ibtidaiyah Vol. 6, No. 1, Juli-Desember 2021 


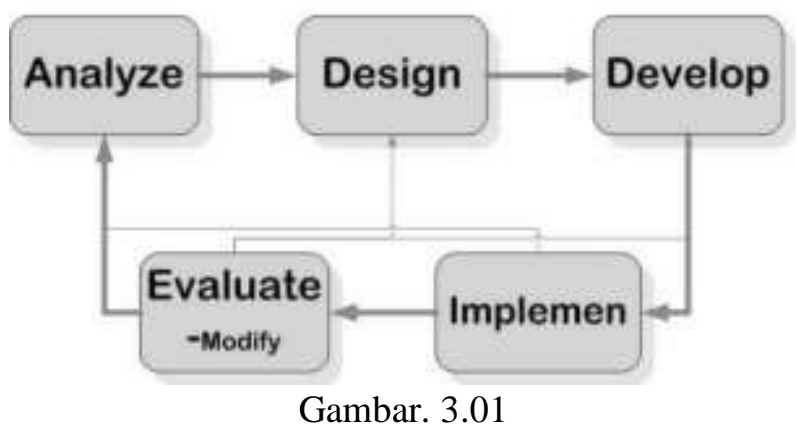

Adapun rincian pada tahapannya adalah pertama menentukan siswa, pembelajaran dan media yang digunakan, kedua tahap desain pembuatan media, ketiga tahap pengembangan media, keempat menggunakan media untuk pembelajaran dengan code barcode, terakhir kelima mengevaluasi media pembelajaran dengan code barcode.

\section{HASIL DAN PEMBAHASAN}

a. Deskripsi hasil tahap analysis (analyze)

Produk yang dikembangkan yaitu berupa media pembelajaran dengan code barcode. Tahapan pertama yang dilakukan yaitu tahap analyze dengan menganalisis dan mengidentifikasi masalah serta mencari yang dibutuhkan dalam pengembangan media belajar pada saat pembelajaran online dengan smartphone. Hasil dari analisis awal-akhir telah diketahui Peserta didik dalam menggunakan smartphone harus diawasi dan dibantu orang tua, karena dalam smartphone begitu banyak informasi yang tidak bisa disaring oleh anak-anak, baik dari sesi positif dan negatifnya. Oleh karena itu perlu sesuatu alat yang dapat mengarahkan anak-anak dalam belajar dan lebih terfokus dengan materi pembelajaran. Tahap analisis melihat dari perubahan kondisi perkembangan teknologi dan masuknya wabah virus corona membuat dunia pendidikan memaksa harus menggunakan pembelajaran jarak jauh atau $\mathrm{PJJ}^{6}$. Kondisi ini membuat peserta didik menjadi merasa bosan belajar dengan hanya disuguhkan buku bacaan yang terisi teks dan yang terlebih lagi membuat peserta didik bosan adalah banyaknya tugas yang diberikan oleh pendidik. Tidak ada variasi dalam proses belajar mengajar juga membuat peserta didik bertambah bosan. Maka olah sebab itulah dibuat suatu trobosan baru yang mampu menjadikan peserta didik bersemangat. Untuk menambah variasi dalam pembelajaran dibuatlah kertas satu lembar bisa menampung materi yang bisa ditonton melalui video dengan berupa barcode yang disuguhkan.

\section{b. Deskrispsi tahap desain (design)}

Media yang akan digunakan menyesuaikan dengan kondisi lapangan pada pembelajaran online dengan smartphone. Media yang diperlukan dalam pembelajaran yaitu media yang dapat digunakan adalah media barcode. Media ini merupakan suatu image dua dimensi yang dapat menampilkan data dalam bentuk teks, sehingga mampu menjadi alat interaksi antara guru dan siswa dalam metransfer pengetahuan dan informasi ${ }^{7}$. Media barcode diharapkan mampu menghubungkan pengetahuan dan informasi dari pendidik kepada peserta didik. Adapun tahapan desainnya adalah tahap pembuatan media barcode menggunakan barcode generator versi 3.3.1 pada android adalah sebagai berikut:

${ }^{6}$ priarti Megawanti, Erna Megawati, Dan Siti Nurkhafifah, "Persepsi Peserta Didik Terhadap Pjj Pada Masa Pandemi Covid 19," Faktor: Jurnal Ilmiah Kependidikan 7, no. 2 (20 Juli 2020): 75, https://doi.org/10.30998/fjik.v7i2.6411.

${ }^{7}$ Mustakim, Walanda, dan Gonggo, "Penggunaan Qr Code Dalam Pembelajaran Pokok Bahasan Sistem Periodik Unsur Pada Kelas X Sma Labschool Untad,” 216.

Al-Madrasah: Jurnal Ilmiah Pendidikan Madrasah Ibtidaiyah Vol. 6, No. 1, Juli-Desember 2021 


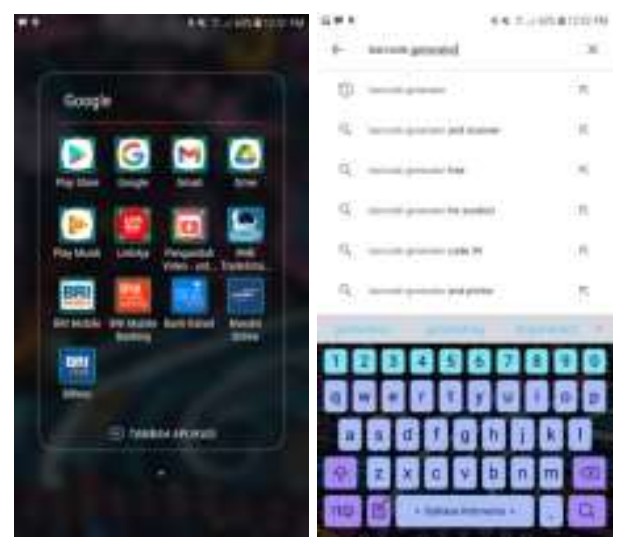

Gambar. 4.01
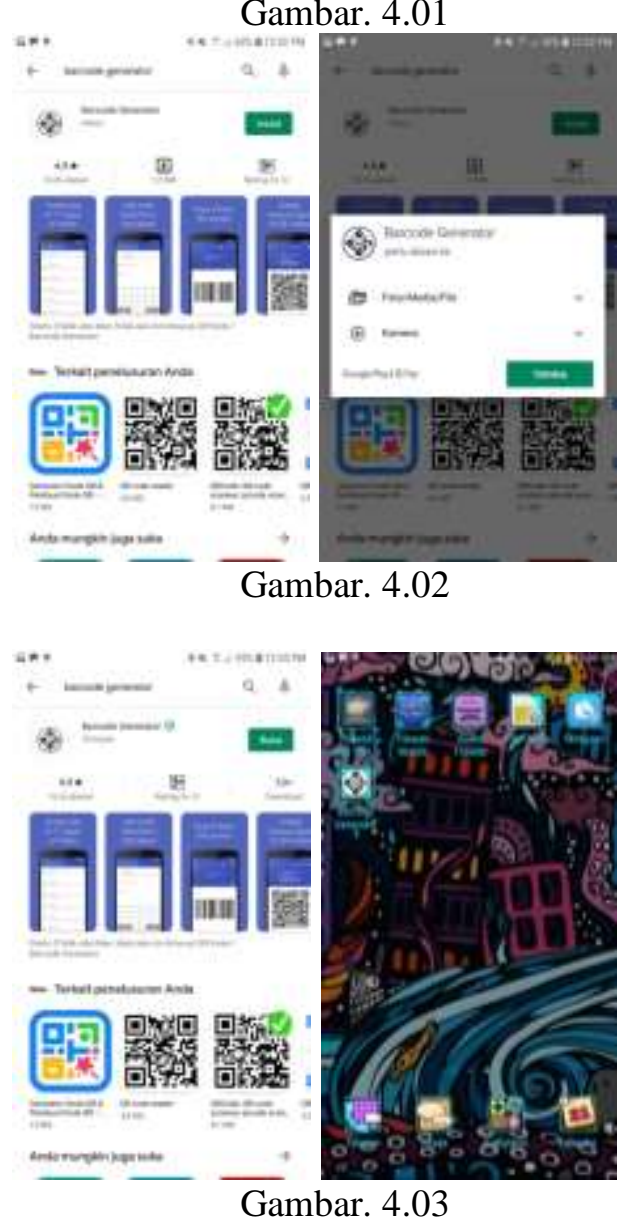

1. Hidupkan smartphone dan buka aplikasi play store $\square$ pada android.

2. Pada kolom pencarian ketikan kata kunci "barcode generator" lalu klik searching.

3. Setelah ditemukan barcode generator lalu klik instal seperti gambar. $4.02 \mathrm{~m}$ lalu kembali klik terima setelah itu tunggu proses penginstalan.
4. Setelah terinstal akan muncul tulisan buka , maka bisa diklik langsung tulisannya atau bisa dicari pada emot icon pada layar yang bertuliskan barcode generator. 

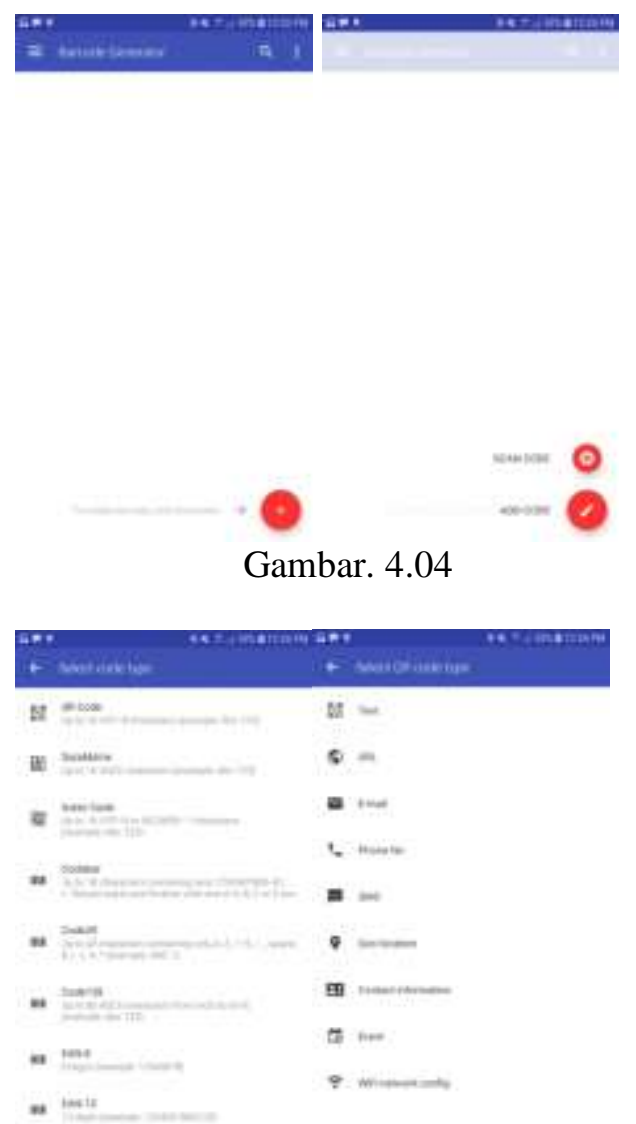

Gambar. 4.05

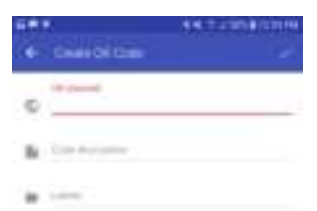
9. Langkah selanjutnya setelah klik URL maka akan dimintanya menuliskan URL, maka kita tulis URL yang sudah disiapkan.

7. Lalu lanjutkan dengan klik QR Code $g x+\infty$ yang berada di atas / urutan paling awal.

8. Setelah QR Code diklik akan menu yang bisa kita pilih, namun karena kita membuat barcode yang nantinya akan mencul video, maka pilih URL seperti pada gambar. 4.05 o.'.

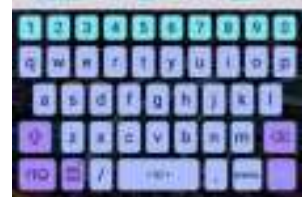

Gambar. 4.06

Vol. 6, No. 1, Juli-Desember 2021 


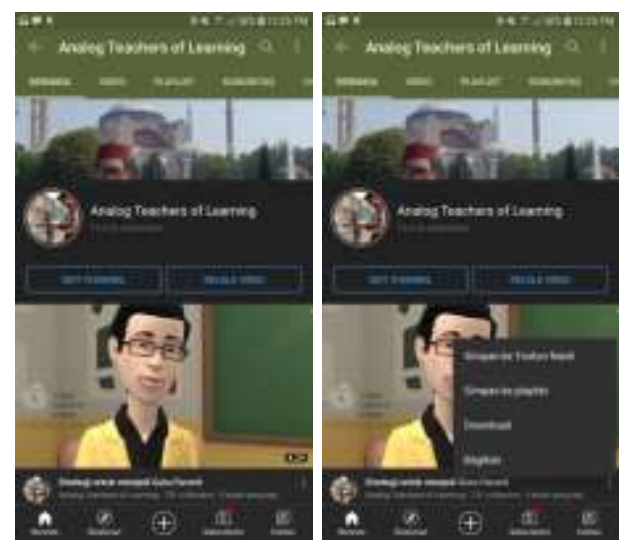

Gambar. 4.07

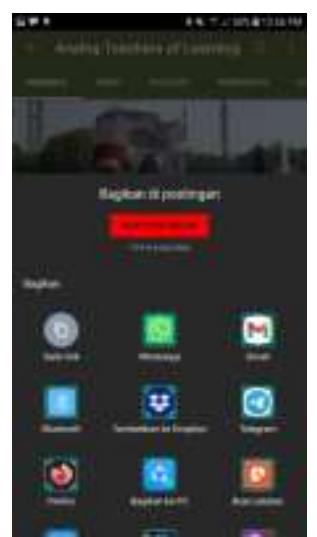

Gambar. 4.08
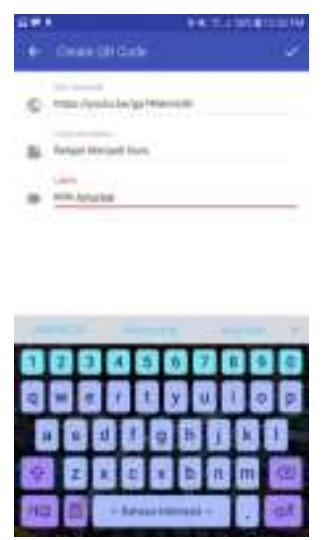

Gambar. 4.09
10. Pada gambar. 4.07 adalah di mana masuk pada situs youtube ${ }^{8}$ untuk mengambil URL atau bisa pilih pada berbagi untuk mendapatkan salinan URL. Contoh URL adalah seperti ini: https://youtu.be/ga74hkimU8I

11. Pada gambar. 4.08 bagian ini terlihat menu untuk salin link 0 , bisa juga untuk berbagi langsung gambar barcode melalui aplikasi whatsApp $\$$, bisa juga berbagi langsung menggunakan aplikasi gmail $\mathrm{O}$, bisa juga berbagi melalui aplikasi telegram 밈, bisa juga berbagi melalui aplikasi bluetooth $\square$, dan berbagai macam aplikasi sosial lainnya.

12. Lalu kembali lagi pada bagian gambar. 4.08, di mana link URL siap untuk di tempel atau paste pada bagian stanners setelahnya beri nama pada bagian = anar mudah saat mencari pada nanti. Terakhir berilah lagi nama pada label untuk menggolongkan file barcodenya seperti terlihat pada gambar - En-m. Maka persiapan pembuatan kode barcode sudah selesai.

${ }^{8}$ Ririn Puspita Tutiasri, Niko Kurniawan Laminto, dan Karim Nazri, "Pemanfaatan Youtube Sebagai Media Pembelajaran Bagi Mahasiswa Di Tengah Pandemi Covid-19” 2, no. 2 (10 Oktober 2020): 1, http://ejurnal.ubharajaya.ac.id/index.php/KOMASKAM/article/view/311.

Al-Madrasah: Jurnal Ilmiah Pendidikan Madrasah Ibtidaiyah

Vol. 6, No. 1, Juli-Desember 2021 

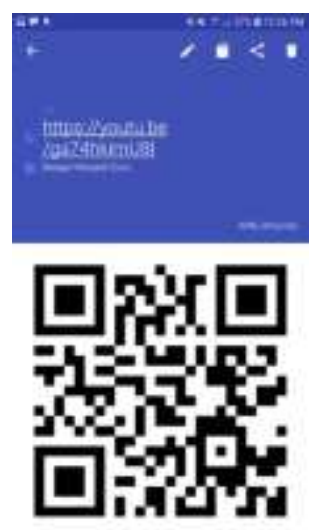

Gambar. 4.10
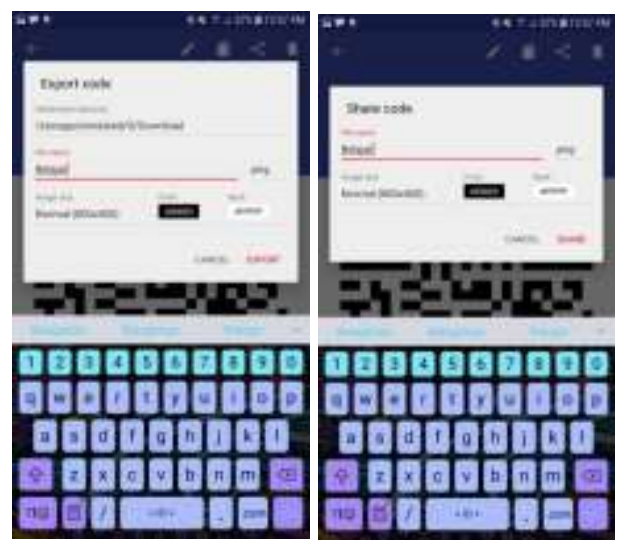

Gambar. 4.11
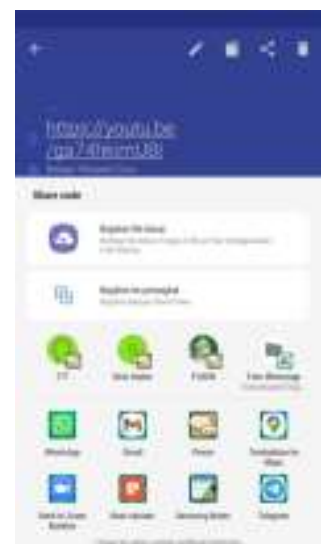

Gambar. 4.12
13. Setelah persiapan semua telah selesai, maka akan muncul gambar barcode yang terlihat seperti gambar. 4.10 yang siap untuk digunakan dalam pembelajaran kertas satu lembar. Maka untuk save gambar code barcode bisa klik 1 pada bagian kanan atas atau bisa juga pilih berbagi / share pada gambar $\mathbf{8}$ yang ada di bagian atas di samping gambar save.

14. Pada gambar. 4.11 ketika klik gambar save , nanti tampilannya seperti gambar. 13 di samping dan apabila klik gambar share $\mathbf{8}$ maka tampilannya akan seperti di samping. Kemudian beri nama untuk mudah mengenali gambar barcode.

15. Pada klik share $\mathbf{A}$, akan muncul gambar. 4.12 seperti di samping kemudian bisa dibagikan sesuai dengan yang dikehendaki melalui aplikasi sosial media yang dimiliki.

Demikianlah cara membuat gambar barcode yang nantinya akan dimasukkan pada RPP yang sudah dibuat untuk dijadikan media pembelajaran kertas satu lembar.

\section{c. Deskripsi Hasil Tahap Pengembangan (develop)}

Tahapan develop adalah tahapan validasi oleh ahli media. Berdasarkan hasil validasi diperoleh data berupa penilaian tentang kelayakan media barcode sebagai suatu media yang layak dan dapat digunakan karena sudah memenuhi kelengkapan standar suatu media pembelajaran karena memiliki langkah-langah yang jelas dan sangat mudah untuk diikuti hanya perlu memperbesar tampilan dari gambar dan huruf agar lebih jelas. 
d. Deskripsi Hasil Implementasi

Tahapan implementasi merupakan tahapan uji coba di lapangan dengan skala kecil yang bertujuan untuk mengetahui kelayakan dari suatu media sebelum digunakan secara luas. Penilaian dilakukan dengan menilai kepraktisan atau keterbacaan dari media barcode melalui pengisian angket oleh siswa. Implementasi atau uji coba pendahuluan media barcode kertas satu lembar diterapkan pada pelajaran IPS kelas 4, dengan Materi Pokok Karakteristik Geografis Wilayah Indonesia dengan sub Materi Letak Astonomis Wilayah Indonesia. Dijelaskan dalam barcode yang ada dengan rincian mengenal Wilayah Indonesia, letak Indonesia dengan diapit oleh dua Benua, Indonesia Wilyah Negara Maritim. Hasil dari uji coba pada siswa didapatkan bahwa media barcode sangat mudah untuk diterapkan pada pembelajaran karena siswa mendapat kemudahan dalam belajar materi. Tanggapan siswa tentang media barcode ini sangat efisien, efektif dan kekinian.

e. Tahap evaluasi (Evaluate)

Tahapan akhir yaitu tahapan evaluasi yang merupakan tahapan menilai secara keseluruhan dari uji sebelumnya menjadi suatu kesimpulan akhir tentang kelayakan dari media yang sudah dikembangkan. Berdasarkan hasil uji validasi pengembangan media barcode secara keseluruhan sudah lengkap dan sudah layak digunakan untuk kegiatan belajar mengajar di kelas. Walaupun media barcode sudah memperoleh hasil yang layak, namun peneliti tetap melakukan revisi tambahan supaya media yang dihasilkan bisa digunakan secara maksimal dan bermanfaat untuk kegiatan pembelajaran secara keseluruhan.

\section{KESIMPULAN}

Barcode merupakan teknologi yang bisa membantu siswa belajar secara mandiri menggunakan kertas satu lembar yang sudah ditaruh gambar barcode. Kemudian siswa untuk dapat menggunakan gambar barcode harus menghubungkannya dengan smartphone yang terkoneksi jaringan. Adapun langkah-langkah guru dalam membuat media barcode adalah sebagai berikut: Membuat RPP-membuat video-upload video ke youtube-salin link video youtube-buat barcode menggunakan aplikasi barcode generator.

\section{DAFTAR PUSTAKA}

Albeta, Sri Wilda, Nofianti Nofianti, dan Sri Rahmandani. "Peranan Turnamen Berbasis Ict Dengan Aplikasi Quizizz Terhadap Pembelajaran Kimia." Jurnal Pendidikan Kimia Universitas Riau 5, no. 1 (28 Januari 2020): 11-15. https://doi.org/10.33578/jpkunri.v5i1.7778.

Dewi, Nanda, R. Eka Murtinugraha, dan Riyan Arthur. "Pengembangan Media Pembelajaran Interaktif Pada Mata Kuliah Teori Dan Praktik Plambing Di Program Studi S1 Pvkb Unj." Jurnal Pensil : Pendidikan Teknik Sipil 7, no. 2 (24 Agustus 2018): 95-104. https://doi.org/10.21009/pensil.7.2.6.

Media, Kompas Cyber. "Diumumkan Awal Maret, Ahli: Virus Corona Masuk Indonesia dari Januari." KOMPAS.com. Diakses 22 November 2020. https://www.kompas.com/sains/read/2020/05/11/130600623/diumumkan-awalmaret-ahli--virus-corona-masuk-indonesia-dari-januari.

Megawanti, Priarti, Erna Megawati, dan Siti Nurkhafifah. "PERSEPSI PESERTA DIDIK TERHADAP PJJ PADA MASA PANDEMI COVID 19." Faktor : Jurnal Ilmiah $\begin{array}{llllll}\text { Kependidikan } & 7, \quad \text { no. } & 2 & (20 \text { Juli 2020): 75-82. }\end{array}$ 
https://doi.org/10.30998/fjik.v7i2.6411.

Mustakim, Sartika, Daud K. Walanda, dan Siang Tandi Gonggo. "Penggunaan Qr Code Dalam Pembelajaran Pokok Bahasan Sistem Periodik Unsur Pada Kelas X Sma Labschool Untad." Jurnal Akademika Kimia 2, no. 4 (30 November 2013): 215221-221.

Nindia Taradisa, 160209063. "Kendala yang Dihadapi Guru Mengajar Daring Pada Masa Pandemi Covid-19 di Min 5 Banda Aceh." Kendala yang Dihadapi Guru Mengajar Daring Pada Masa Pandemi Covid-19 di Min 5 Banda Aceh, 20 Agustus 2020, 111.

Rayanto, Yudi Hari, dan Sugianti. Penelitian Pengembangan Model Addie Dan R2d2: Teori \& Praktek. Pasuruan: Lembaga Academic \& Research Institute, 2020.

Syarifuddin. "Bimbingan Penggunaan Google Form Untuk Pembelajaran IPS Pada Madrasah di Banua Enam | Syarifuddin | Manhaj: Jurnal Penelitian dan Pengabdian Masyarakat." Manhaj: Jurnal Penelitian dan Pengabdian Masyarakat 9, no. 1 (2020): 45-58. http://dx.doi.org/10.29300/mjppm.v9i1.3002.g2479.

Tutiasri, Ririn Puspita, Niko Kurniawan Laminto, dan Karim Nazri. "Pemanfaatan Youtube Sebagai Media Pembelajaran Bagi Mahasiswa Di Tengah Pandemi Covid-19" 2, no. 2 (10 Oktober 2020). http://ejurnal.ubharajaya.ac.id/index.php/KOMASKAM/article/view/311.

Wirasasmita, Rasyid Hardi, dan Muhammad Zamroni Uska. "Pengembangan Media Pembelajaran Berbasis Buku Digital Elektronic Publication (Epub) Menggunakan Software Sigil Pada Mata Kuliah Pemrograman Dasar." Edumatic: Jurnal Pendidikan Informatika 1, no. 1 (27 Desember 2017): 11-16. 